\title{
Influence of different seasons and row arrangements on growth and yield of maize and kenaf and mechanical properties of kenaf fibre in maize/kenaf intercrop
}

\author{
Amujoyegbe B. J.*, Ogbonna N. S. and O. K. Akinbo \\ Department of Crop Production and Protection, Faculty of Agriculture, Obafemi Awolowo University, Ile-Ife, Osun State, \\ Nigeria. \\ *Corresponding author. Email: bamujo@oauife.edu.ng, bjamujoyegbe@gmail.com
}

Copyright $@ 2016$ Amujoyegbe et al. This article remains permanently open access under the terms of the Creative Commons Attribution License 4.0, which permits unrestricted use, distribution, and reproduction in any medium, provided the original work is properly cited.

Received 9th June, 2016; Accepted 11th October, 2016

\begin{abstract}
Four field experiments were carried out from 2012 to 2013 to assess the influence of different seasons and row arrangements on growth, yield of maize and kenaf and mechanical properties of kenaf fibre in maize/kenaf intercrop at lle-Ife, Nigeria. Four maize/kenaf component ratios of 1 row of maize alternated with 1 row of kenaf (1:1), 1 row of maize alternated with 2 rows of kenaf (1:2), 2 rows of maize alternated with 1 row of kenaf (2:1) and 2 rows of maize alternated with 2 rows of kenaf (2:2) and two control treatments namely; sole maize and sole kenaf were laid in a randomized complete block design in three replications. Growth parameters such as plant height, stem diameter, leaf area and plant biomass were measured on the component crops from four weeks after planting and subsequently at two weeks interval until physiological maturity of maize. Yield parameters such as ear length, ear diameter, kernel per ear, shelling percentage and grain yield/ha were measured on maize while retted fibre yield/ha was measured on kenaf at flowering. The mechanical properties of the kenaf fibre were determined on the retted kenaf. Data were subjected to analysis of variance and the significant mean values were separated using Duncan's Multiple Range Test at $p \leq 0.05$. Results indicated that season and row arrangement significantly $(p \leq 0.05)$ affected growth and grain yield of maize and fibre yield of kenaf. The 1:2 and 2:2 row arrangements compared favourably with sole cropping on the mechanical properties of kenaf fibre. Row arrangement of 1:2 and 2:2 and sole cropping significantly $(p \leq 0.05)$ affected tensile strength of kenaf fibre relative to 2:1 and 1:1 row arrangement. Thus, lower maize/kenaf ratio would promote optimum yield and good fibre quality of kenaf fibre.
\end{abstract}

Keywords: Kenaf, maize, mechanical properties, intercrop, row arrangement, yield.

\section{INTRODUCTION}

Intercropping is a form of mixed cropping in which two or more crops are cultivated on the same land area and in time, in order to increase the productivity of land per unit area and as a natural model for designing sustainable agriculture and land conservation for fertility restoration (Andrew and Kassam, 1976). It is a strategy used by farmers especially in the developing countries to increase crop yields, crop diversity and stability of crop production and financial returns (Kuchinda and Ogunwole, 2000). Row intercropping is a form of intercropping which involves at least one of the component crops arranged in rows in either replacement or additive methods with the intension of planting many crops in order to reduce competition for growth resources in intercropping and thereby, improving intercropping practices as a means of yield increase in crop production (Natarajan and Willey, 1985). A variation of row cropping in the developed countries includes strip row arrangement, where multiple crops are grown together in strips wide enough to permit separate crop production using machines but close enough for the crops to interact.

Maize (Zea mays L.), of the Poaceae family which has 
been recognized as a common component of notable cropping systems in effect of which the crop has assumed the status of a 'local cash crop' with about $75 \%$ of the cultivated land area grown to it in association with other crops (Ayeni, 1987). The increasing importance of maize has been attributed to its growing utilization in food industries, livestock feed and human consumption. The yield of maize however, varies from variety to variety and from location to location and depends on cultural practices adopted. Kenaf (Hibiscus cannabinus L.) is one of the most versatile annual fibre crops grown throughout the world. It belongs to the Malvaceae family and indigenous to Africa. It was the first to be identified as a close substitute to jute in the manufacturing of rope, twine and sack. Its core is used in a wide range of paper production, carpet backing and burlap manufacturing (Wilson et al., 1965). Kenaf is also used as components of several building materials, car bumpers, medicine, food additives, animal beddings and ethanol production Kenaf plant consists of an inner thick core of short woody fibres ( 0.5 to I $\mathrm{mm}$ thick) and an external bark with fibres of 3 to $4 \mathrm{~mm}$ thick. The bast fibres have been reported to be of better quality than the core fibres. However, both can be utilized in various blends for the production of pulp (Petrini et al., 1994).

Agricultural researchers have in the past promoted monoculture but this has been met with very little success among small holder farmers whose preference and problems have underscored the importance of intercropping in their traditional cropping systems (Kuchinda and Ogunwole, 2000). In recent times, the issue of risk minimization and efficient use of resources through intercropping is receiving increasing attention in cropping systems research. Francis and Adipala (1994) and Tsubo et al. (2003) attributed these to the consideration that achieving sustainable production may not only involve mechanized rotational monoculture cropping systems used in developed countries but also the poly-culture cropping systems used in developing countries.

Intercropping maize and kenaf has enormous potential in terms of improving yields and income (Saka et al., 2007). According to Raji (2008), intercropping of kenaf with sorghum gave results that indicated yield advantages. Studies by Asante (1993) showed that maize and kenaf intercrop produced high kenaf yield. However, most of these studies did not clearly indicate the type of row arrangement that best suits the component crops performance in combination. Also little documentation is available on the fibre quality of kenaf due to intercropping or other cultural practices carried out in the process of production. The objective of this work therefore was to evaluate the influence of different seasons and row arrangements on growth and yield of maize and kenaf and mechanical properties of kenaf fibre in maize/kenaf intercrop.

\section{MATERIALS AND METHODS}

The studies were conducted during the early and late seasons (April to July and August to November respectively) of 2012 and 2013 at the Teaching and Research Farms of the Obafemi Awolowo University (OAU) Ile-Ife, Nigeria. Geographically, OAU is situated within the rain forest zone, on latitude $7^{\circ} 28^{\prime} \mathrm{N}$ and longitude $4^{0} 33^{\prime} \mathrm{E}$ at an elevation of about $200 \mathrm{~m}$ above sea level. It experiences approximately eight months (March to October) of bimodal rainfall. It has about four months (November to February) of dry season each year with slight irregularity in the rainfall distribution pattern. The mean yearly rainfall for 2012 and 2013 were 1436.9 $\mathrm{mm}$ and $1548.7 \mathrm{~mm}$ respectively. The experimental plots were previously cropped to cassava and allowed to fallow for one cropping season before the experiments. The soils of the experimental sites belong to Iwo series derived from coarse-grained granite gneiss parent rock and classified as Ultisol (low base status forest soils). It is well drained, grayish brown to brownish red with predominantly high acidity clay - kaolinite (Harpstead, 1973). They were generally loamy with $\mathrm{pH}$ of 5.63 to 5.71 . Exchangeable $\mathrm{K}$ was $0.37 \mathrm{cmol} \mathrm{kg}^{-1}$, total $\mathrm{N}$ was $0.14 \%$ and available $\mathrm{P}$ was $2.65 \mathrm{ppm}$ (Kang and Balasubramanian, 1990)

Maize var. QPM (Quality Protein Maize) and kenaf var. IFEKEN 400 were used for the experiment. Four maize: kenaf component ratios of 1 row of maize alternated with 1 row of kenaf (1:1), 1 row of maize alternated with 2 rows of kenaf (1:2), 2 rows of maize alternated with 1 row of kenaf (2:1) and 2 rows of maize alternated with 2 rows of kenaf (2:2) and two control treatments namely; sole maize and sole kenaf were arranged in a Randomized Complete Block Design (RCBD) in three replications. Urea was applied to maize at $150 \mathrm{~kg} \mathrm{~N} / \mathrm{ha}$ in two equal split-applications at three weeks after planting and at tasseling. Single superphosphate and Muriate of potash were broadcasted at $26 \mathrm{~kg} \mathrm{P} / \mathrm{ha}$ and $26 \mathrm{~kg} \mathrm{~K} / \mathrm{ha}$ before harrowing. The maize and kenaf seeds were treated with $200 \mathrm{~g}$ metalaxyl-M $+20 \mathrm{~g}$ difenoconazole $+200 \mathrm{~g}$ thiamethoxam $/ \mathrm{kg}$ shortly before planting to control soil borne pests and pathogens. The component crops were planted on ridges using replacement series (Osiru and Willey, 1972). Each plot measured $8 \times 5 \mathrm{~m}$, to contain eight ridges at 1 meter apart; crops were planted at two stands per hole with maize and kenaf interspaced at 0.3 and $0.2 \mathrm{~m}$ respectively. Net plot made up of rows 3 to 6 were used for yield data while rows 2 and 7 were used for destructive sampling to determine growth parameters. Chemical weed control was carried out using a formulated mixture of $270 \mathrm{~g}$ Altrazine $+150 \mathrm{~g}$ metolachlor and $276 \mathrm{~g}$ of paraquat which was applied two weeks after plants emergence at the rate of 2 litres per hectare. Supplementary weed control was carried out as and when necessary during the experimentation period. 
Table 1. Effects of season and row arrangement on height $(\mathrm{cm})$ of maize and kenaf in maize/kenaf intercrop.

\begin{tabular}{|c|c|c|c|c|}
\hline Treatment & 4WAP & 6WAP & 8WAP & 10WAP \\
\hline \multicolumn{5}{|l|}{ Seasons } \\
\hline \multicolumn{5}{|l|}{ Maize } \\
\hline Early & 42.59 & 97.70 & 183.23 & 266.58 \\
\hline Late & 29.77 & 85.11 & 110.26 & 208.41 \\
\hline LSD & 1.93 & 4.82 & 3.96 & 5.52 \\
\hline F-test & * & * & * & * \\
\hline \multicolumn{5}{|l|}{ Kenaf } \\
\hline Early & 31.6 & 69.06 & 121.53 & 205.75 \\
\hline Late & 23.5 & 65.39 & 90.63 & 154.10 \\
\hline LSD & 2.34 & 2.49 & 3.11 & 3.34 \\
\hline F-test & * & * & * & * \\
\hline \multicolumn{5}{|c|}{ Row arrangements } \\
\hline \multicolumn{5}{|c|}{ Maize } \\
\hline $1: 1$ & 35.91 & 93.42 & 147.35 & 237.84 \\
\hline $2: 2$ & 37.29 & 89.10 & 146.32 & 237.10 \\
\hline $2: 1$ & 35.74 & 90.23 & 145.61 & 234.52 \\
\hline $1: 2$ & 36.33 & 91.14 & 147.91 & 238.12 \\
\hline LSD & 2.93 & 4.83 & 3.97 & 5.53 \\
\hline F-test & $\mathrm{ns}$ & $\mathrm{ns}$ & $\mathrm{ns}$ & $\mathrm{ns}$ \\
\hline \multicolumn{5}{|l|}{ Kenaf } \\
\hline $1: 1$ & 25.24 & 64.18 & 104.85 & 173.67 \\
\hline $2: 2$ & 25.98 & 69.89 & 107.16 & 184.64 \\
\hline $2: 1$ & 25.43 & 62.81 & 105.14 & 176.42 \\
\hline $1: 2$ & 26.06 & 70.34 & 107.22 & 188.32 \\
\hline LSD & 0.95 & 2.49 & 3.11 & 5.35 \\
\hline F-test & ns & * & ns & * \\
\hline
\end{tabular}

*Significant at $5 \%$ probability level, ns, not significant. WAP, Weeks after planting.

Plant height, stem diameter and plant biomass were measured on five randomly tagged plants in the four middle rows (Whingham, 1975) at 3, 6, 8 and 10 weeks after planting (WAP). Dry matter was taken on three randomly selected plants obtained from rows 2 and 7 . The above ground parts were separated into leaves, stems and cob or head (depending on the stage) and oven-dried to a constant weight at $75^{\circ} \mathrm{C}$. Yield parameters namely; number of ears per plot, number of grains per ear, ear length, dry kernel weight, hundredkernel weight and shelling percentage (S\%) were collected on maize at harvest. Grain yield was converted to tonnes per hectare according to Shanmugasundaram (1979).

Harvested kenaf were retted in cold water for two weeks to expose the fibre content of the plant. After water retting procedure, the fibres were then clean with water and sun-dried to obtain dry fibre in tonnes per hectare.
The retted fibres were subjected to mechanical stress by analyzing the tensile stress and strain using universal testing machine INSTRON machine (model 5566) according to ASTM D5083 (1996). Data were subjected to analysis of variance (ANOVA) to determine the effects of the treatments on the parameters. Duncan's Multiple Range Test (DMRT) was used to separate means where $F$ values were significant at $p \leq 0.05$. (Steele and Torrie, 1980; Gomez and Gomez, 1984). All analyses were done with the Statistical Analysis System (SAS) software version 8.1 .

\section{RESULTS}

Effects of season and row arrangement on height $(\mathrm{cm})$ of maize and kenaf in maize/kenaf intercrop is shown in Table 1. Plant height were significantly $(p \leq 0.05)$ influen- 
Table 2. Effects of season and row arrangement on stem girth $(\mathrm{mm})$ of maize and kenaf in maize/kenaf intercrop.

\begin{tabular}{lcccc}
\hline Treatment & 4WAP & 6WAP & 8WAP & 10WAP \\
\hline Seasons & & & & \\
Maize & 9.28 & 18.59 & 18.69 & 21.64 \\
Early & 6.90 & 15.15 & 18.66 & 20.20 \\
Late & 0.33 & 0.75 & 1.24 & 1.56 \\
LSD & $*$ & $*$ & $\mathrm{~ns}$ & $\mathrm{~ns}$ \\
F-test & & & & \\
Kenaf & 4.15 & 7.14 & 11.82 & 17.24 \\
Early & 4.24 & 7.69 & 10.21 & 14.29 \\
Late & 0.23 & 1.15 & 0.76 & 2.23 \\
LSD & $\mathrm{ns}$ & $\mathrm{ns}$ & $*$ & $*$ \\
F-test & & & & \\
& & & & \\
Row arrangements & & & & \\
Maize & 7.86 & 17.02 & 18.85 & 21.08 \\
$1: 1$ & 8.29 & 16.70 & 18.52 & 20.78 \\
$2: 2$ & 7.76 & 16.42 & 18.57 & 21.32 \\
$2: 1$ & 8.11 & 17.12 & 19.13 & 22.43 \\
$1: 2$ & 0.79 & 0.75 & 1.47 & 2.45 \\
LSD & $\mathrm{ns}$ & $\mathrm{ns}$ & $\mathrm{ns}$ & $\mathrm{ns}$ \\
F-test & & & & \\
Kenaf & 5.32 & 7.44 & 10.77 & 15.55 \\
$1: 1$ & 4.81 & 7.36 & 11.22 & 16.03 \\
$2: 2$ & 5.22 & 7.45 & 10.31 & 15.74 \\
$2: 1$ & 5.34 & 7.61 & 10.52 & 16.11 \\
$1: 2$ & 0.78 & 0.32 & 1.04 & 0.77 \\
LSD & $\mathrm{ns}$ & $\mathrm{ns}$ & $\mathrm{ns}$ & $\mathrm{ns}$ \\
F-test & &
\end{tabular}

*Significant at 5\% probability level, ns, not significant. WAP, Weeks after planting.

ced by season. Both maize and kenaf were observed to be taller in early season across the sampling period. Row arrangements were found to significantly $(p \leq 0.05)$ affect the height of kenaf at 6 and 10 weeks after planting but had no effect on maize height. Kenaf were observed to be significantly $(p \leq 0.05)$ taller at $1: 2$ and $2: 2$ combination of maize and kenaf compared to other combination.

Effects of season and row arrangement on stem girth $(\mathrm{mm})$ of maize and kenaf in maize/kenaf intercrop in Table 2 indicated that early season significantly $(\mathrm{p} \leq$ 0.05 ) increased the girth of maize at weeks 4 and 6 , but increased that of kenaf at weeks 8 and 10. However, seasons and row arrangement were observed to significantly $(p \leq 0.05)$ affect the dry matter of the two crops (Table 3 ). Higher dry matter was observed during the early season compared to the late season as the growing period of the crops increased. While 1:2 maize:kenaf combination resulted in higher dry matter of maize, the result was not significantly $(p \leq 0.05)$ different from the dry matters obtained from 1:1 and 2:2 combinations especially at 10 WAP. However for kenaf, $2: 2$ and 1:2 combination of maize:kenaf resulted in highest dry matter while the least value was obtained from 2:1 combination.
Effect of row arrangement on yield and yield components of maize and kenaf in maize/kenaf intercrop is shown in Table 4. Grain yield of maize and fibre yield of kenaf were significantly $(p \leq 0.05)$ influenced by row arrangement. Although, crops planted sole had the highest yield in both crops, this was significantly ( $p \leq$ 0.05 ) followed by $2: 1$ row arrangement for maize yield and 1:2 for fibre yield for kenaf. The least grain yield was observed at 1:2 maize:kenaf row arrangement and also the least fibre yield at 2:1 maize:kenaf row arrangement.

The effect of row arrangement on the mechanical properties (tensile strength) of kenaf fibre in maize/kenaf intercrop is generated in Figure 1. The row arrangement significantly $(p \leq 0.05)$ affected the mechanical properties as the effect of 2:2, 1:2 were not significantly ( $p \leq 0.05$ ) different from the impact of sole planting on kenaf fibre.

\section{DISCUSSION}

Early season planting of maize and kenaf which resulted in significantly $(P \leq 0.05)$ higher growth and yield performance compared to late season cropping may be due to favourable weather conditions during the early seasons. Christou et al. (2000), Saka et al. (2007) and 
Table 3. Effects of season and row arrangement on dry matter (g) of maize and kenaf in maize/kenaf intercrop.

\begin{tabular}{|c|c|c|c|c|}
\hline Treatment & 4WAP & 6WAP & 8WAP & 10WAP \\
\hline \multicolumn{5}{|l|}{ Seasons } \\
\hline \multicolumn{5}{|l|}{ Maize } \\
\hline Early & 7.69 & 61.68 & 140.41 & 160.52 \\
\hline Late & 7.65 & 54.30 & 101.12 & 125.43 \\
\hline LSD & 0.15 & 1.70 & 6.39 & 3.31 \\
\hline F-test & ns & * & * & * \\
\hline \multicolumn{5}{|l|}{ Kenaf } \\
\hline Early & 8.52 & 33.86 & 146.83 & 160.95 \\
\hline Late & 5.15 & 29.86 & 117.50 & 137.51 \\
\hline LSD & 1.11 & 1.90 & 2.95 & 2.05 \\
\hline F-test & * & * & * & * \\
\hline \multicolumn{5}{|c|}{ Row arrangements } \\
\hline \multicolumn{5}{|c|}{ Maize } \\
\hline $1: 1$ & 7.80 & 59.85 & 119.92 & 144.97 \\
\hline $2: 2$ & 7.51 & 56.36 & 121.50 & 141.23 \\
\hline $2: 1$ & 7.77 & 55.72 & 118.41 & 137.54 \\
\hline $1: 2$ & 7.21 & 61.33 & 123.42 & 146.61 \\
\hline LSD & 0.43 & 1.68 & 2.40 & 3.32 \\
\hline F-test & ns & * & * & * \\
\hline \multicolumn{5}{|l|}{ Kenaf } \\
\hline $1: 1$ & 6.01 & 28.26 & 128.66 & 145.20 \\
\hline 2:2 & 6.21 & 34.35 & 135.23 & 151.53 \\
\hline $2: 1$ & 6.11 & 26.54 & 121.25 & 141.48 \\
\hline $1: 2$ & 6.05 & 33.72 & 127.58 & 155.32 \\
\hline LSD & 0.36 & 1.90 & 2.95 & 3.45 \\
\hline F-test & ns & * & * & * \\
\hline
\end{tabular}

*Significant at $5 \%$ probability level, ns, not significant. WAP, Weeks after planting.

Table 4. Effect of row arrangement on yield and yield components of maize and kenaf in maize/kenaf intercrop.

\begin{tabular}{ccccccc}
\hline \multirow{2}{*}{$\begin{array}{c}\text { Row } \\
\text { Arrangement }\end{array}$} & $\begin{array}{c}\text { Ear length of } \\
\text { maize }(\mathbf{c m})\end{array}$ & $\begin{array}{c}\text { Cob diameter } \\
\text { of maize }(\mathbf{m m})\end{array}$ & $\begin{array}{c}\text { Number of } \\
\text { grains per cob } \\
\text { of maize }\end{array}$ & $\begin{array}{c}\mathbf{1 0 0} \text { grain } \\
\text { weight }(\mathbf{g}) \text { of } \\
\text { maize }\end{array}$ & $\begin{array}{c}\text { Grain yield of } \\
\text { maize }(\mathbf{t} / \mathbf{h a})\end{array}$ & $\begin{array}{c}\text { Fibre yield of } \\
\text { kenaf }(\mathbf{t} / \mathbf{h a})\end{array}$ \\
\hline $1: 1$ & 13.52 & 46.61 & 502.01 & 33.24 & 2.60 & 1.52 \\
$2: 2$ & 13.92 & 46.89 & 484.45 & 35.25 & 2.72 & 1.59 \\
$2: 1$ & 13.43 & 47.31 & 491.55 & 34.62 & 3.91 & 0.81 \\
$1: 2$ & 15.55 & 47.23 & 501.71 & 33.51 & 1.41 & 2.54 \\
SOLE & 15.27 & 47.16 & 491.94 & 35.33 & 4.88 & 2.70 \\
LSD & 0.81 & 1.41 & 26.43 & 2.25 & 0.21 & 0.06 \\
F-test & $*$ & $\mathrm{~ns}$ & $\mathrm{~ns}$ & $\mathrm{~ns}$ & $*$ & $*$ \\
\hline
\end{tabular}

*Significant at $5 \%$ probability level. Ns, not significant.

Maryam et al., (2011) reported that influence of weather variation associated with different agronomic practices have modifying effect on the growth and development of crop plants. To date, the challenges of maize growers in Nigeria is finding the narrow window of appropriate rows arrangement coupled with crop combination that will 


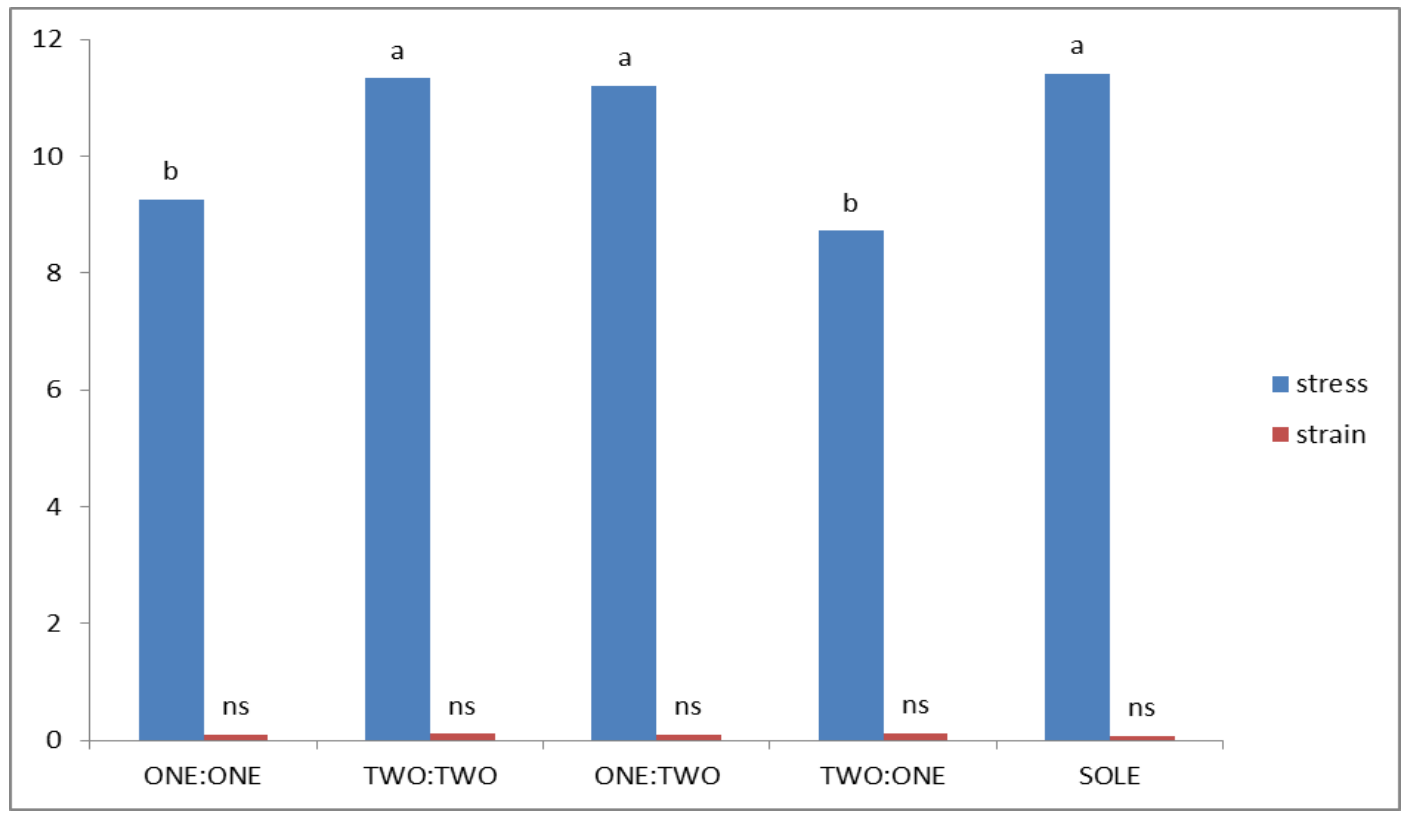

Figure 1. Effect of row arrangement on stress and strain of kenaf fiber. Bars with similar alphabets are not significantly different using Duncan's Multiple Range Test at 5\%probability level. Ns, not significant at $5 \%$ probability level.

enable them to optimize available land for crop production.

The effect of row arrangements on growth and yield of the component crops were significant $(P \leq 0.05)$ as 2:1 and 2:2 row arrangements produced higher growth and grain yield while $1: 2$ favoured fibre yield of kenaf. This could be attributed to population density which will either increase or decrease inter-competition among the combining crops. For grain yield, maize/kenaf component ratios of 2 rows of maize alternated with 1 row of kenaf (2:1) and 2 rows of maize alternated with 2 rows of kenaf (2:2) increased the population of maize while 1 row of maize alternated with 2 rows of kenaf (1:2) favoured kenaf population which also reduced inter-species competition between maize and kenaf consequently resulted to higher grain or fibre yield depending on the crop of emphasis. The work of Kuchinda and Ogunwole, (2000) had shown that kenaf responded slowly to soil nutrient utilization than maize. Nitrogen, phosphorus, potassium and water are considered as the major limiting factors in crop growth, development and finally economic yield (Parry et al., 2005). The root architecture and proximity of adjacent crops is proportional to the level of competition hence, the level of yield depression suffered by a crop stand (Egbe, 2010). Intercropping affects vegetative growth of component crops and therefore the spatial and temporal arrangements is vital to yield of intercropped plants (Thayamini and Brintha, 2010). According to Saka et al. (2007), maize grows rapidly in the early stages and dominates kenaf and therefore results in yield reduction in kenaf in plots where maize was dominating. This might be due to interspecies competition for resources and thus resulted in aggressive usage of available nutrients by maize in sole and in intercrop (Saka et al., 2007).

Intercropping significantly ( $P \leq 0.05)$ affected the mechanical quality of the fibres obtained from the kenaf plant. Kenaf under sole cropping, combination of 1 row of maize alternated with 2 kenaf (1:2) and 2 rows of maize alternated with 2 rows of kenaf (2:2) gave significantly $(P \leq 0.05)$ higher tensile strength (which is an indicator of higher mechanical strength or better fibre quality) compared to $2: 1$ and $1: 1$. This could be attributed to less competition interspecies stands which then resulted to bigger and stronger fibres. The sole cropping of kenaf had no competition with maize and therefore produced bigger and stronger fibre. Higher competition in maize/kenaf component ratios of 2 rows of maize alternated with 1 row of kenaf (2:1) and 1 row of maize alternated with 1 row of kenaf $(1: 1)$ could be responsible for strength reduction compared to $2: 2$ and sole.

\section{Conclusion}

It could be concluded that seasons and row arrangements influenced the growth and yield of maize and kenaf, and the mechanical properties of kenaf fibre in maize/kenaf intercrop. Early season planting increased yield while crop combination at 1:2 and 2:2 maize:kenaf 
rows arrangement significantly $(P \leq 0.05)$ favoured yield and mechanical stress of the fibres obtained.

To encourage small holder farmers to cultivate kenaf (a non-food crop) in order to improve fibre industry, cultivation of kenaf with maize which serves as staple food crop will require a crop combination of maize:kenaf in the ratio of $1: 2$ or 2:2 for optimum production.

\section{CONFLICT OF INTEREST}

The authors declare that they have no conflict of interest.

\section{REFERENCES}

Andrew, D. J., \& Kassam, A.H., (1976). The Importance of Multiple Cropping in Increasing World Food Supplies. In: Multiple Cropping, Papendick, R.I., A. Sanchez and G.B. Triplett (Eds.). American Society of Agronomy, Madison, WI, USA. 5, 1-10.

Asante, A. K. (1993). Spatial arrangement on maize and kenaf intercropping. Ghana Journal of Agricultural Science, 24 (27), 99-104.

Ayeni, A. O. (1987). Maize production in Nigeria: Problems and prospects. Journal of Food and Agriculture, 2, 123-129.

Christou, M., Mardikis, M., \& Alexopoulou, E. (2000). The influence of sowing time and plant population on kenaf growth and yields. Biomass and Energy Crops II. AAB: Warwick, p.55.

Egbe, O. M. (2010). Effects of plant density of intercropped soybean with tall sorghum on competitive ability of soybean and economic yield at Otobi, Benue State, Nigeria. Journal of Cereals and Oilseeds 1(1), 1-10.

Francis, C. A., \& Adipala, E. (1994). Tropical intercropping systems: What is their future? African Crop Science Journal. 2, 131-133

Gomez, K. A., \& Gomez, A. A. (1984). Statistical procedure for agricultural research. $2^{\text {nd }}$. Edition, John Wiley \& Sons Co N.Y. Pp. 680.

Harpstead, M. (1973). A classification of some Nigerian soils. Soil Sci. 116, 437-443

Kang, B. T., \& Balasubramanian, V. (1990). Long Term Fertilizer Trial on Alfisols in West Africa. In Transactions of XIV International Soil Science Society (ISSS) congress, Kyoto, Japan. p. 350.

Kuchinda, N. C., \& Ogunwole, J. O. (2000). Effects of dates and row arrangement on crop growth and yield in kenaf/maize mixture in the northern guinea savanna of Nigeria. Journal of Sustainable Agriculture and Environment. 2, 251-256.
Maryam, A. B., Saied, K. K., Seyed, H. S., Mandana, D., Khodadad, M., \& Mohammad, G. (2011). A Study on Effects of Planting Dates on Growth and Yield of 18 Corn Hybrids (Zea mays L.) American Journal of Experimental Agriculture 1(3), 110-120.

Natarajan. M., \& Willey, R. W. (1985). Effect of row arrangement on light interception and yield in sorghumpigeon pea intercropping. Journal of Agricultural Science (Cambridge), 104, 263-270.

Parry, M. A. J., Flexas, J., \& Medrano, H. (2005). Prospects for crop production under drought: research priorities and future directions. Annals of Applied Biology, 147, 211-226.

Petrini, C., Bazzocch, R. I., \& Montalti, P. (1994). Yield potential and adaptation of Kenaf (Hibiscus cannabinus) in northcentral Italy. Industrial Crops and Products Journal 3, 11-15.

Raji, J. A. (2008). The Feasibility of Intercropping Kenaf with Sorghum in a Small-Holder Farming System. Journal of Sustainable Agriculture, 32(2), 355 - 364.

Saka, J. O., Adeniyan, O. N., Akande, S. R., \& Balogun, M. O. (2007). An Economic Evaluation of Intercropping African Yam Bean, Kenaf and Maize in the Rain Forest Zone of Nigeria. Middle-East Journal of Scientific Research 2 (1), 01-08.

SAS Institute (2001). SAS user's guide. Statistics version $5^{\text {th }}$ Ed. SAS Institute, Cory, NC, U.S.A.

Shanmugasundaram, S. (1979). International Cooperator's Guide. Evaluating AVDRC (Asian Vegetable Research and Development Centre) soybeans. AVDRC Shanhua, Taiwan. Pp. $79-125$

Steel, S. G. D., \& Torrie, J. H. (1980). Principles and procedure of statistics. A biometrical approach. McGraw-Hill Book Co. Inc. London. p. 663.

Thayamini, H. Seran \& Brintha, I. (2010). Review on Maize Based Intercropping. Journal of Agronomy, 9, 135-145.

Tsubo, M., Walker, S., \& Mukhala. E. (2003). Comparisons of radiation use efficiency of mono-inter-cropping systems with different row orientations. Field Crop Research. 71, 17-29.

Whingham, D. K. (1975). International soybean variety improvement: First report of results. University of Illinois, Urban Campaign. INTSDY series, 8, 11.

Wilson, F. D., Summers, T. E., Joyner, J. F., Fishler, D. W., \& Seale, C. C. (1965). 'Everglades 41' and 'Everglades 71', two new varieties of kenaf (Hibiscus cannabinus L.) for the fiber and seed. Florida Agricultural Experimental Station, Belle Glade. Cir. S-168. 